\title{
KARAKTERISTIK SOSIAL EKONOMI PEDAGANG SEKTOR INFORMAL DI PASAR BERSEHATI KOTA MANADO
}

\author{
Suwito La Uto \\ Nordy F. L. Waney \\ Agnes E. Loho
}

\begin{abstract}
This study aims to examine the social economic characteristic of informal sector traders. The research took place from October to December 2017 at Market of Bersehati Manado, Calaca Urban Village, Wenang Sub-district, Manado City. Collection method in this research is primary and secondary data. Sampling method in this research is done by Accidental Sampling. The number of samples were taken in this study were 30 respondents consists of 15 respondents of vegetable sellers and 15 respondents of spice merchants. The research results showed that vegetable sellers and spice merchants who working in the informal sector, most of them have a simple background, both traders are able to meet the needs of everyday families with their own capital and basic capital of trust. They earned an average income of vegetable sellers IDR 63,868 and spice merchant IDR 276,950. *eprm*.
\end{abstract}

Keywords: characteristics, socio-economic, vegetable traders, spice traders, informal sector, market of Bersehati Manado, Manado City.

ABSTRAK

Penelitian ini bertujuan untuk mengkaji karakteristk sosial ekonomi pedagang sektor informal di Pasar Bersehati Manado. Penelitian berlangsung dari bulan Oktober-Desember 2017 di Pasar Bersehati Manado, Kelurahan Calaca, Kecamatan Wenang, Kota Manado. Data yang dikumpulkan dalam penelitian ini adalah data primer dan data sekunder. Metode pengambilan sampel dalam penelitian ini dilakukan dengan dengan mengambil sampel secara kebetulan bertemu (accidental sampling) dengan peneliti. Jumlah sampel yang diambil dalam penelitian ini adalah 30 responden yakni 15 responden pedagang sayur dan 15 responden pedagang rempah-rempah. Hasil penelitian menunjukkan bahwa pedagang sayur dan pedagang rempah-rempah yang bekerja di sektor informal kebanyakan memiliki latar belakang yang sederhana, pedagang mampu memenuhi kebutuhan keluarga sehari-hari dengan memiliki modal sendiri dan modal asas percaya. Pendapatan rata-rata pedagang sayur sebesar Rp 63,868 sedangkan pedagang rempah-rempah Rp 276,950.

Kata kunci: karakteristik, sosial ekonomi, pedagang sayur dan pedagang rempah-rempah, sektor informal, pasar bersehati, Kelurahan Calaca, Kecamatan Wenang, Kota Manado.

\section{PENDAHULUAN}

\section{Latar Belakang}

Kesejahteraan masyarakat merupakan salah satu tujuan yang diharapkan oleh setiap daerah yang ada di kabupaten/kota di Provinsi Sulawesi Utara. Berbagai upaya dirancang dan dilaksanakan oleh pemerintah daerah sematasama guna meningkatkan pertumbuhan bagi daerah itu sendiri dan selanjutnya diharapkan akan berdampak positif bagi kesejahteraan masyarakatnya. Salah satu upaya yang dilakukan pemerintah daerah dalam mencapai tujuannya yakni dengan adanya pelaksanaan pembangunan.

Nugroho (2010), menyatakan bahwa pembangunan sosial ekonomi yang mencerminkan kesejahteraan masyarakat pada suatu wilayah diharapkan dapat terwujud oleh upaya-upaya yang dilakukan pemerintah daerah. Upaya pelaksanaan pembangunan pada setiap daerah merupakan bagian dari terselenggaranya pelaksanaan kualitas hidup masyarakat. 
Kualitas hidup yang ada dilingkungan masyarakat merupakan kualitas yang dijalankan setiap hari. Menurut Nussbaum dan Sen (1993) kualitas yang dimaksud adalah kualitas dari segi materi: seperti keadaan rumah, bahan rumah, bahan pangan, dan kualitas dari fisik seperti: kesehatan tubuh. Kualitas hidup mempunyai peran penting yang dilakukan oleh setiap individu maupun kelompok. Oleh karena itu perlu tindakan yang lebih baik agar kualitas hidup dapat berjalan sesuai dengan keinginan yang diharapkan sebagai upaya pembangunan di Kota Manado.

Kota Manado adalah salah satu kota di provinsi Sulawesi Utara yang menjadi tujuan utama dan menjadi alasan untuk mencari pekerjaan karena pembangunannya maju. Masyarakat desa atau masyarakat urban, mencoba mengadu nasib dari segala usaha untuk perubahan ekonomi. Agar pembangunan ekonomi mampu berjalan dengan baik serta mencapai tujuan yang diharapkan, maka tidak hanya menumbuhkan dan mengembangkan program-program resmi pemerintah yang dikenal dengan sektor formal. Namun juga menumbuhkan usaha kecil yang dikelola oleh pribadi-pribadi yang sangat bebas menentukan bagaimana cara dan dimana usaha tersebut dijalankan. Usaha yang sangat efektif sebagai masyarakat itu disebut sektor informal.

Sektor formal merupakan sektor yang yang mempunyai usaha yang dilindungi oleh badan hukum dan mempunyai izin untuk bekerja disektor formal sedangkan sektor informal merupakan sektor yang mempunyai usaha yang banyak dimintai oleh masyarakat urban atau masyarakat desa setempat. Sektor informal memiliki karakteristik seperti jumlah unit usaha yang banyak dalam skala kecil, kepemilikan oleh individu atau keluarga, teknologi yang sederhana dan padat tenaga kerja, tingkat pendidikan dan ketrampilan yang rendah, produktivitas tenaga kerja yang rendah dan tingkat upah yang juga relatif lebih rendah dibandingkan sektor formal (Rachbini dan Hamid,1994).
Masyarakat urban dan setempat yang kebanyakan dari mereka berasal dari desa yang dipilih adalah profesi pedagangkaki lima, seperti yang kita ketahui jenis usaha pedagang kaki lima adalah masuk kategori usaha berskala kecil, tujuan utama mereka hanyalah sekedar untuk bisa memenuhi kebutuhan primer mereka sehari-hari.

Strategi prasarana yang mereka tetapkan masih sederhana atau kalau diamati kerja mereka sekedar asal laku. Motivasi pekerja adalah memperoleh pendapatan yang cukup untuk sekedar mempertahankan hidup (survival). Mereka harus tinggal di pemukiman kumuh, dimana pelayanan publik seperti listrik, air bersih, transportasi, kesehatan, dan pendidikan yang sangat minim.

Pedagang kaki lima yang dimaksud adalah pedagang yang terdapat di pasar tradisional. Pasar tradisional merupakan tempat berdagang yang dimiliki oleh setiap pedagang kaki lima seperti pedagang sayur dan pedagang rempah-rempah. Pedagang sayur dan pedagang rempah-rempah merupakan salah satu usaha yang kegiatan penjualan eceran dan melaksanakan pemberian jasa kepada konsumen atau pembeli.

Pasar bersehati adalah pasar yang berada di kecamatan wenang Pasar Bersehati merupakan pasar terbesar dengan jumlah pedagang dan kios terbanyak. Pengunjung yang datang kepasar ini juga masih sangat banyak. Padatnya aktifitas seringkali menimbulkan kemacetan pada waktu-waktu tertentu karena pasar terletak di samping jalan raya lokal.

Pasar Bersehati juga memiliki keunggulan bersaing alamiah yang tidak dimiliki secara langsung oleh pasar modern. Selain lokasi yang strategis dan area penjualan yang luas, keragaman barang yang lengkap, harga cukup rendah, sistem tawar menawar yang menunjukkan keakraban antara penjual dan pembeli merupakan keunggulan dari Pasar Bersehati. 
Modal yang digunakan oleh pedagang sayur dan pedagang rempah-rempah relatif rendah karena, modal yang digunakan menggunakan modal sendiri dan modal kepercayaan atau modal titip dagangan setelah hasil dagangan telah terjual maka hasil atau uangnya diberikan pada pemilik dagangan yang memberikan kepercayaan tersebut. Tinggi rendahnya modal akan berpengaruh pada pendapatan usaha yang dijalankan setiap hari oleh karena itu, perlu adanya penelitian yang mengetahui sosial ekonomi pedagang di sektor informal. Berdasarkan pemikiran diatas dan untuk mengumpulkan bukti empirik maka diperlukan penelitian "Karakteristik Sosial Ekonomi Pedagang Sektor Informal di Pasar Bersehati Kota Manado".

\section{Kerangka Berpikir Penelitian}

Kerangka berpikir penelitian merupakan alur pikir yang logis yang bertujuan untuk menjelaskan secara garis besar yang akan dilaksanakan dilapangan atau tempat penelitian di Pasar Bersehati Manado. Pasar Bersehati adalah salah satu objek tempat penelitian untuk memenuhi objek penelitian dan data yang lengkap di buat suatu skema berpikir penelti agar mempermudah alur dari tujuan penelitian. Tujuan dan masalah yang diteliti di Pasar Bersehati Manado terdapat dua karakteristik yaitu secara sosial dan ekonomi.

Pendapatan merupakan karakteristik dari hasil akhir yang ingin dicapai pedagang kakilima atau pedagang sayur dan pedagang rempah-rempah yang bekerja disektor informal, dalam penelitian ini pendapatan dapat dipengaruhi oleh karakteristik atau faktor sosial antara lain karakteristik umur dapat menggambarkan produktivitasnya sehingga mempengaruhi pendapatannya, karakteristik kedua adalah tingkat pendidikan dapat mempengaruhi pola pikir seseorang dalam pengambilan keputusan berdagang dalam usaha, karakteristik ketiga adalah daerah asal dapat mempengaruhi pengangguran yang ada desa untuk merubah atau mencari pekerjaan disektor informal.

Karakteristik keempat status perkawinan atau tanggungan dapat mempengaruhi jumlah pendapatan anak istri atau suami dan saudara yang tinggal didalam rumah semakin banyak tanggungan keluarga atau yang telah menikah maka kepala keluarga akan lebih banyak atau lebiih usaha untuk memperoleh pendapatan dalam sekali penjualan. Karakteristik curahan waktu dapat mempengaruhi pendapatan karena semakin lama atau semakin banyak waktu seseorang berdagang maka pendapatan yang didapat bisa melewati upah Upah Minum Provinsi (UMP). Kerangka berpikir penelitian dapat dilihat pada Gambar 1.

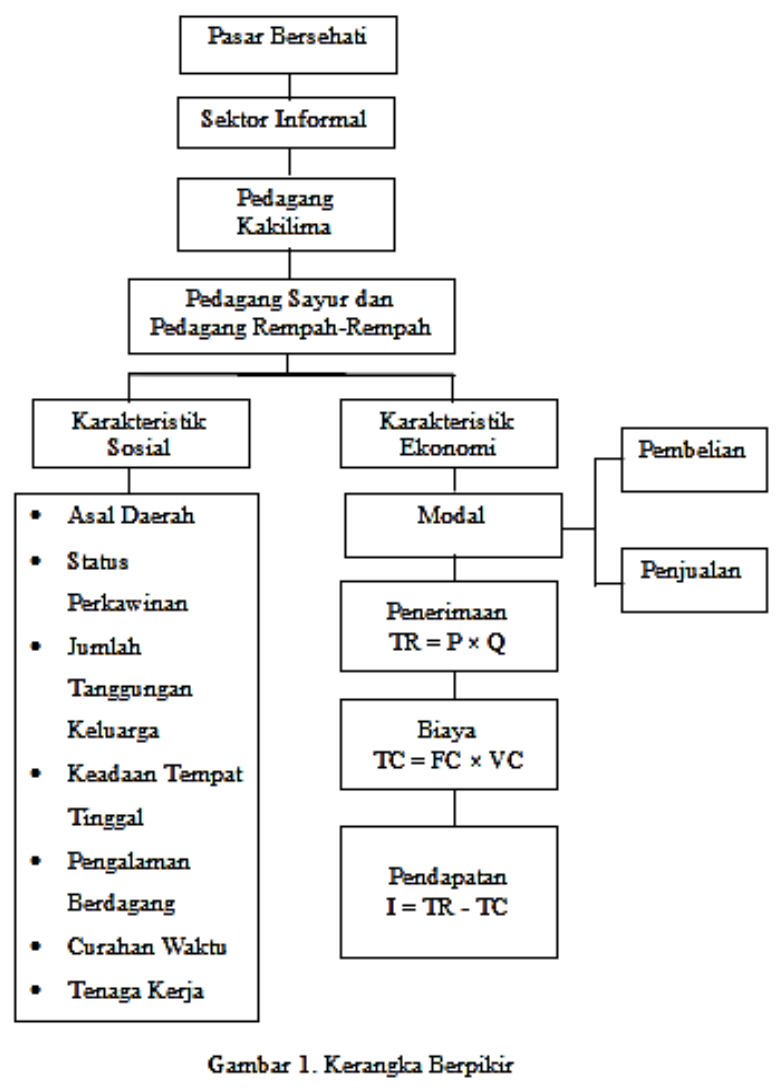

\section{Rumusan Masalah}

Berdasarkan latar belakang yang telah di uraikan, maka rumusan masalah dalam penelitian ini adalah bagaimana karakteristik sosial ekonomi pedagang sektor informal di Pasar Bersehati Kota Manado. 


\section{Tujuan Penelitian}

Penelitian ini bertujuan untuk mengkaji karakteristk sosial ekonomi pedagang sektor informal di Pasar Bersehati Kota Manado.

\section{Manfaat Penelitian}

Manfaat dalam penelitian ini adalah diharapkan dapat memberikan pengetahuan kepada pengelola pasar dan pedagang tentang karakteristik sosial ekonomi pedagang sektor informal di Pasar Bersehati Kota Manado.

\section{METODOLOGI PENELITIAN}

\section{Tempat dan Waktu Penelitian}

Penelitian ini dilakukan di Pasar Bersehati Manado Kelurahan Calaca Kecamatan Wenang. Penelitian berlangsung selama 3 (tiga) bulan mulai dari persiapan hingga penyusunan laporan hasil penelitian yaitu dari bulan Oktober 2017 sampai bulan Desember 2017.

\section{Metode Pengumpulan Data}

Metode pengumpulan data survei yang digunakan dalam penelitian ini adalah data primer dan data sekunder. Data primer diperoleh melalui metode wawancara dengan mengunakan daftar pertanyaan atau kuesioner kepada pedagang sayur dan pedagang rempah-rempah di Pasar Bersehati Kota Manado. Data sekunder diperoleh dari jurnal, skripsi, buku yang menyangkut dengan judul penelitian, PD. Pasar Kota Manado, Dinas Pasar Bersehati dan Badan Pusat Statistik Kota Manado.

\section{Metode Pengambilan Sampel}

Populasi dari penelitian ini adalah pedagang sayur dan pedagang rempahrempah. Metode pengambilan sampel dalam penelitian ini dilakukan dengan Accidental Sampling yaitu dengan mengambil sampel secara kebetulan bertemu dengan peneliti. Jumlah sampel yang diambil dalam penelitian ini adalah 30 responden yakni 15 responden di pedagang sayur dan 15 responden pada pedagang rempah-rempah. pengambilan sampel pada pedagang sayur dilakukan selama 15 hari dan pengambilan sampel pedagang rempah-rempah berlangsung 16 hari.

\section{Variabel Penelitian}

Variabel-variabel dalam penelitian ini adalah

a. Identitas pedagang sektor informal yang terdiri atas:

1) Umur merupakan usia responden yang bekerja disektor informal (tahun).

2) Pendidikan formal merupakan pendidikan terakhir padaresponden.

b. Karateristik sosial pedagang sayur dan pedagang rempah-rempah pada sektor informal yang terdiri atas:

1) Daerah asal merupakan tempat pedagang berasal dari desa yang mencari pekerjaan di kota yakni dari Manado, Gorontalo, dan Ternate.

2) Status perkawinan merupakan status perkawinan yakni: tidak kawin dan kawin.

3) Tanggungan keluarga merupakan banyaknya anggota keluarga seperti sumai/istri, anak dan orang lain yang menjadi tanggunan kepala keluarga (KK).

4) Keadaan Tempat tinggal merupakan status kepemilikan pedagang sayur dan rempah-rempah seperti; milik, sewa, dan menumpang.

5) Pengalaman berdagang merupakan pengalaman bekerja sebelum bekerja jadi pedagang sayur dan pedagang rempah-rempah (tahun).

6) Waktu berdagang merupakan waktu berdagang dalam satu hari (per jam). 
7) Tenaga Kerja merupakan tenaga kerja yang ikut membantu selama proses berdagang dalam satu hari. Tenaga kerja terdiri dari tenaga kerja dalam keluarag (TKDK) dan tenaga kerja luar keluarga (TKLK).

8) Modal Kepercayaan yaitu modal yang diambil langsung dari tempat pelelangan sayur atau rempah-rempah dan setelah itu hasil dari penjualan akan langsung berika hasilnya ke pemilik pelelangan atau pemilik sayur dan rempah-rempah.

9) Motivasi pedagang merupakan semangat berdagang seperti dorongan dalam diri dan dorongan keluarga.

c. Karakteristik sosial pedagang sayur dan pedagang rempah-rempah pada sektor informal yang terdiri atas

1) Modal adalah modal yang digunakan untuk kegiatan berdagang yaitu modal sendiri (Rp).

2) Penerimaan yaitu jumlah sayur dan rempah-rempah yang dijual pada konsumen $(\mathrm{Rp} / \mathrm{Kg})$.

3) Pengeluaran adalah semua biaya yang dikeluarkan selama kegiatan berdagang yang terdiri dari biaya variabel yaitu biaya pembelian, biaya pengangkutan, biaya tenaga kerja dan biaya kantong plastik dan biaya tetap yaitu biaya sewa tempat, biaya kebersihan, biaya distribusi dan biaya listrik ( $R p)$.

4) Pendapatan merupakan penerimaan dikurangi dengan pengeluaran dari total biaya tetap dan total biaya variabel ( $R p)$.

\section{Analisis Data}

Hasil penelitian dianalisis secara deskriptif (descriptive analysis) dengan bantuan tabel di sertai uraian-uraian secara verbal dan mendalam.

\section{HASIL DAN PEMBAHASAN}

\section{Deskripsi Umum Pasar Bersehati Kota Manado}

Pasar bersehati adalah pasar yang berada di kecamatan wenang Pasar Bersehati merupakan pasar terluas 50,000 $\mathrm{Ha}$ dengan jumlah pedagang dan 178 kios atau los terbanyak di Pasar Tradisional Manado. Padatnya aktifitas seringkali menimbulkan kemacetan pada waktu-waktu tertentu karena pasar terletak di samping jalan raya local dan memiliki keunggulan bersaing alamiah yang tidak dimiliki secara langsung oleh pasar modern. Selain lokasi yang strategis dan area penjualan yang luas, keragaman barang yang lengkap, harga yang terjangkau murah, sistem tawar menawar yang menunjukkan keakraban antara penjual dan pembeli juga mendapat nilai ksusus di mata masyarakat setempat dan pemerintah Kota Manado Lokasi Pasar Tradisional Bersehati terletak Jl. Nusantara, Kelurahan Calaca, Kecamatan Wenang, Kota Manado. Secara Geografis letak Kota Manado berada pada $1^{\circ} 30^{\prime} 1[\mathrm{~B} 1]^{\circ} 40^{\prime}$ Lintang Utara dan $124^{\circ} 40^{\prime} 126[\mathrm{~B} 2]^{\circ}$ 50' Bujur Timur. Adapun batas-batas dari Kecamatan Wenang yaitu:

- Sebelah Utara : Sungai Jengki dan Kecamatan Singkil

- Sebelah Timur : Kecamatan Tikala

- Sebelah Selatan : Kecamatan Sario dan Kecamatan Wanea

- Sebelah Barat : : Teluk Manado

Letak pasar bagian ujung utara kecamatan Wenang dan mempunyai jarak dengan kantor kecamatan wenang kurang lebih enam kilometer. Kedudukan pasar berada di kelurahan Calaca yang berhadapan dengan kantor lurah Calaca dan Pasar Bersehati Manado berdekatan dengan pusat perbelanjaan Pasar 45 yang hanya berjarak 400 meter. Jalan masuk yang menghubungkan pasar bersehati dengan konsumen dan produsen yaitu jalan aspal yang telah dilalui kendaraan jenis angkutan kota yang menuju tuminting, banjer, dan paal II. Sarana angkutan yang digunakan para konsumen pada umumnya angkutan kota sedangkan sarana angkutan yang digunkan pedagang untuk mengangkut barang dagangan yang di gunakan seperti gerobak dan mobil pick up dengan cara 
pikulan atau pengangkutan. Pedagang di sektor informal khsusnya pedagang yang berjualan sayur dan rempah-rempah terdiri dari berbagai latar belakang suku seperti Manado, Gorontalo dan Ternate. Kebanyakan dari pedagang di dominasi oleh kaum pria dan wanita serta tenaga kerja yang ikut membantu berasal dari dalam keluarga dan luar keluarga.

Kegiatan pesar Bersehati berlangsung setiap hari dan mulai dari pagai jam 04.00 Wita sampai dengan malam jam 23.00 Wita serta paling ramai dikunjungi konsumen berbelanja di pagi hari jam 07.00 sampai jam 09.00 Wita.

\section{Profil Pedagang Sektor Informal}

Profil pedagang informal ini oleh peneliti didasarkan atas gambaran tentangidentitas informan yang di sesuaikan dengan kriteriakriteria dalam penentuan subjek atau informan yang mendukung di perolehnya hasil penelitian yang berkesinambungan dengan realita sosial yang terjadi didalam kehidupan masyarakat Kelurahan Calaca Kecamatan Wenang untuk lebih jelasnya disajikan profil informan sebagai berikut.

\section{Umur Responden}

Umur sangat mempengaruhi kemampuan fisik seseorang dalam menjalankan aktifitas dan produkstifitas kerja. Umur responden dapat dilihat pada Tabel 1.

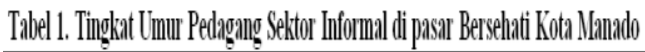

\begin{tabular}{|c|c|c|c|c|}
\hline & Peldgging Sagyir & \multicolumn{2}{|c|}{ Pethqgang Rempal - Rempal } & \multirow[b]{2}{*}{ Persentase $\left(0_{0}\right)$} \\
\hline$\overline{\mathrm{TmmII}}$ & Responden (ornang) & Persentlase $\left(\theta_{0}\right)$ & Responden (orang) & \\
\hline$<30$ & 4 & 26,7 & 2 & 13 \\
\hline $31 \cdot 45$ & 6 & 40 & 7 & 46, \\
\hline$>45$ & j & 33,3 & 6 & 4 \\
\hline Jumlah & 15 & 100 & 15 & 10 \\
\hline
\end{tabular}

Tabel 1 menunjukkan pedagang dengan produktivitas kerja dari umur $<30$ mulai dari umur 23 tahun sampai $>45$ tahun yaitu 50 tahun. Kedua jenis pedagang dengan umur produktivitas di bawah $<30$ masih kuat atau mampu berdagang sampai satu hari. Umur 3145 atau umur menengah aktivitas kerjanya hanya sampai sore menjelang malam, dengan alasan untuk mengurusi kebutuhan keluarga. Umur $>45$ tahun aktivitas kerjanya hanya setengah hari karena kondisi tubuh tidak terlalu kuat di bandingkan umur di bawah $<30$. Kesimpulan tingkat umur dari kedua jenis pedagang diatas bahwa umur sangat mempengaruhi produktivitas kerja, jadi produktivitas kerja yang paling berpengaruh oleh aktivitas dan produktivtas kerja pada umur $>45$.

\section{Pendidikan Responden}

Pendidikan mempengaruhi seseorang dalam menentukan sikap, peningkatan intelektual dan bahkan pengambilan keputusan untuk mengelolah usaha berdagangnya. Tingkat pendidikan dapat, dilihat pada Tabel 2.

Tabel 2. Timgkat Pendidikan Pedaggang Selitor Informal did Pasar Berselati Kota Manado

\begin{tabular}{|c|c|c|c|c|}
\hline \multirow[b]{2}{*}{ Tingkat Pendidkan } & \multicolumn{2}{|c|}{ Pedaggang Saxturan } & \multicolumn{2}{|c|}{ Pedaggang Rempal-Rempah } \\
\hline & Responden (orang) & Persentase $(0)$ & Responden (oriang) & Persentase $\left(\%_{0}\right)$ \\
\hline SD & 4 & 26,7 & 5 & 33,3 \\
\hline SMP & 6 & 40 & 7 & 46,7 \\
\hline SMA & 4 & 26,6 & 3 & 20 \\
\hline UNIVERSTIAS & 1 & 6,7 & . & \\
\hline Jumlah & 15 & 100 & 15 & 100 \\
\hline
\end{tabular}

Sumber: Diolah Dari Data Primer, 2017

Pendidikan berkaitan erat dengan bidang pekerjaan dan usaha yang dilakukan di setiap responden yang berdagang sayur dan rempah-rempah. Tabel 2 menunjukkan bahwa pedagang sayur dan pedagang rempahrempah yang memiliki pendidikan (responden) tertinggi adalah Sekolah Menengah Pertama (SMP). Responden yang menempuh pendidikan di SMP merupakan kemampuan studi formal tertinggi dan mempunyai ekonomi yang mampu menyelesaikan Pendidikan formal walaupun tidak sampai jenjang SMA.

Responden yang tidak mampu melanjutkan studi ke jenjang lebih tinggi dalam hal ini yaitu Pendidikan Sekolah Menengah Atas (SMA) mereka tidak bisa melanjutkan studi dengan alasan bahwa faktor ekonomi, dengan alasan faktor ekonomi tersebut mereka berhenti bersekolah tapi, mereka tidak pernah menyerah untuk merubah diri sebagai perubahan ekonomi keluarga. Responden yang menempuh pendidikan dibawah SMA mereka mencari alternatif lain dengan berdagang sayur 
dan rempah-rempah dengan alasan untuk merubah nasib mereka. Hal ini menunjukkan bahwa tingkat pendidikan tidak berpengaruh dalam kegiatan berjualan sayur dan rempahrempah atau dengan kata lain tingkat pendidikan bukanlah prasyarat utama dalam sektor informal melainkan semangat untuk membangun ekonomi disetiap responden.

\section{Karakteristik Sosial Pedagang di Sektor Informal}

\section{Asal Daerah Responden}

Alasan utama responden meninggalkan tempat tinggal yang ada desa yaitu faktor ekonomi artinya responden mencari kehidupan yang lebih baik di Kota Manado. Faktor pembangunan artinya kurang adanya sarana dan prasana yang kurang mendukung akan kebutuhan yang dimiliki responden, fakor Pendidikan artinya rata-rata responden tidak bisa menempuh Pendidikan yang lebih tinggi misalnya skala universitas atau perguruan tinggi. Responden memilih untuk mencari kehidupan yang lebih layak walaupun responden hanya pendidikan rendah. Oleh sebab itu migrasi sangat perlu dilakukan oleh setiap responden karena, dengan adanya alasan yang telah disebutkan diatas bahwa dapat ditarik kesimpulan bahwa responden yang paling banyak melakukan migrasi yaitu dari Gorontalo dan Ternate dan sebagian responden dari Kota Manado yang sudah menjadi penduduk tetap selama proses berdagang. Pada Tabel 3 dapat dilihat asal daerah pedagang sayur dan pedagang rempah-rempah.

Tabel3. Daerah Lsal Pedagano. Sector Informal dil Pasar Bersedati Kota Manado

\begin{tabular}{|c|c|c|c|c|}
\hline & \multicolumn{2}{|c|}{ Pedagang Saỵu } & \multicolumn{2}{|c|}{ Pedagyng Rempal - Rempalh } \\
\hline Daerah Asal & Responden (orragg) & Persentase $\left(\theta_{0}\right)$ & Responden (orang) & Persentase $\left(\theta_{0}\right)$ \\
\hline Manado & 3 & 20 & $?$ & 13,3 \\
\hline Gorontalo & 10 & 66,7 & 13 & 86,7 \\
\hline Temate & 2 & 13,3 & . & . \\
\hline Jumlah & 15 & 100 & 15 & 100 \\
\hline
\end{tabular}

Tabel 3 menunjukkan bahwa responden yang bekerja disektor informal adalah pendatang luar Manado yaitu Gorontalo dan Ternate. Responden yang paling banyak melakukan migrasi atau perpindahan paling banyak terdapat pada 10 orang pedagang sayur dan 13 orang pedagang rempah-rempah dari Gorontalo dan menjadi alasan mereka ke Manado untuk merubah ekonomi dalam keluarga dan sarana prasana yang di Gorontalo masih minim sehinggah mereka melakukan migrasi serta mengikuti teman yang telah lama berdagang di Manado.

\section{Status Perkawinan Responden}

Seseorang yang telah menikah tentunya memiliki tanggung jawab yang besar dibandingkan dengan seseorang yang belum menikah. Tabel 4 menunjukkan status perkawianan responden.

\begin{tabular}{|c|c|c|c|}
\hline \multirow[b]{2}{*}{ Status Perkarinan } & \multirow{2}{*}{ 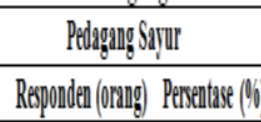 } & \multicolumn{2}{|c|}{ Pedgangerempah - Rempal } \\
\hline & & Responden (Orngg) & Persentase $\left(y_{0}\right)$ \\
\hline Karin & 13 & 15 & 100 \\
\hline BelumKarin & ? & . & \\
\hline Jumlah & 15 & 15 & 100 \\
\hline
\end{tabular}

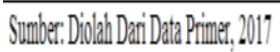

Tabel 4 menunjukkan bahwa rata-rata responden telah kawin atau sudah menikah sebesar 86,7 persen dan 10 persen pedagang rempah-rempah yang paling banyak telah menikah. Responden yang paling banyak menikah menandakan bahwa mereka adalah kepala keluarga yang setiap hari membiayai semua kebutuhan hidup seharihari di Kota Manado. Responden yang belum kawin atau belum menikah terdapat 2 orang orang dengan jumlah persentase terkecil 13,3 persen. Responden yang belum menikah yaitu responden yang masih muda dan belum ada niat untuk memililki keluarga yang sah.

\section{Tanggungan Keluarga Responden}

Tanggungan keluarga di setiap responden merupakan tanggung jawab besar kepala keluarga dan kepala keluarag menjadi tulang punggung yang akan memenuhi semua 
biaya-biaya yang diperlukan dalam keluarga. Tanggungan keluarga pada setiap responden memiliki tanggungan 0-1 sampai $>4$ orang yang tinggal di dalam rumah. Responden yang memiliki tanggungan keluarga yaitu kepala keluarga yang setiap hari membiayai atau menghidupi anggota keluarganya. Setiap hasil dagangangannya dipakai untuk membayar listrik, kebutuhan dalam rumah, dan kebutuhan lain yakni kebutuhan diluar rumah seperti minum, makan, pulsa elektrik dan lain-lain. Tanggungan keluarga pada setiap responden dapat dilihat pada Tabel 5.

Tabel5. Tanggongan Keluarga Pedagang Sektor Informal di Pasar Bersehatit Kota Nanado

\begin{tabular}{|c|c|c|c|c|}
\hline & \multicolumn{2}{|c|}{ Pedagming Saytur } & \multicolumn{2}{|c|}{ Pelagang Rempal-Rempah } \\
\hline $\begin{array}{c}\text { Tangguggan } \\
\text { Keluargan (orrang) }\end{array}$ & Respoulden (orang) & Persentase $\left(\varphi^{\circ}\right)$ & Responden (oriug) & Persentase $(\%)$ \\
\hline $0 \cdot 1$ & 3 & 20 & . & \\
\hline $2 \cdot 3$ & 7 & 46,7 & 7 & 46,7 \\
\hline$>4$ & 5 & 33,3 & 8 & 53,3 \\
\hline Jumlah & 15 & 100 & 15 & 100 \\
\hline
\end{tabular}

Sumber: Diolah Dari Data Primer, 2017

Tabel 5 menunjukkan bahwa jumlah atau banyaknya tanggungan keluarga mempunyai tanggung jawaba akan kebutuhan hidup setiap hari atau semua kebutuhan setiap tanggungan keluarga di tanggung oleh oleh kepala keluarga suami atau istri. Jumlah tanggungan 2 orang pada umumnya pasangan muda berumur dibawah 30 tahun. Responden yang berumur lebih dari 40 tahun memiliki tanggunan lebih dari 4 orang dan anak-anak mereka sudah sudah kawin atau sudah menikah sehingga tidak menjadi tanggungan lagi serta jumlah tanggungan keluarga $2-3$ orang anak-anak mereka sedang mengikuti pendidikan di jenjang SD dan SMA.

\section{Keadaan Tempat Tinggal Responden}

Tempat tinggal pedagang sayur dan pedagang rempah yaitu tempat berlindung dari pengaruh cuaca di luar maupun sebagai tempat berkumpulnya keluarga dalam kehidupan seharihari. Tempat tinggal pedagang sayur dan pedagang rempah-rempah menempati rumah bersama sanak saudara, bersama istri/suami dan anak, serta bersama teman. Status tempat tinggal yang didiami oleh pedagang sayur dan pedagang rempah-rempah dapat dilihat pada Tabel 6.
Tabel 6. Status Kepemilikan Rumah Pedagang Sektor Informal di Pasar Bersehati Kota Manado

\begin{tabular}{lcrcr}
\hline & \multicolumn{3}{c}{ Pedagang Sajur } & \multicolumn{3}{c}{ Pedagang Rempah-Rempah } \\
\hline Status Tempat Tinggal & Responden (0rang) & Persentase $(\%)$ & Responden (orang) & Persentase $(\%)$ \\
\hline Nilik & 10 & 66,7 & 14 & 93,3 \\
Sewa & 3 & 20 & - & - \\
Menumpang & 2 & 13,3 & 1 & 6,7 \\
\hline Jumlah & 15 & 100 & 15 & 100 \\
\hline Sumber:Diolah Dari Data Primer, 2017 & & &
\end{tabular}

Tabel 6 menunjukkan bahwa rata-rata responden diatas menempati rumah sendiri. responden yang telah menempati rumah sendiri merupakan responden yang sudah lama bekerja disektor informal di Manado. Responden yang menempati rumah keluarga serta rumah teman merupakan pedagang yang belum lama berdagang karena biaya untuk merencanakan membangun rumah sendiri belum cukup dengan kendala bahwa pendapatan yang diterima dari hasil kerja belum bisa memenuhi kebutuhan membengun rumah di Kota Manado.

Berdasarkan pada Tabel 8 diatas dapat di katakan bahwa responden telah memiliki kemampuan yang cukup dalam hal kepemilikan tempat tinggal. Namun untuk lebih lengkapnya dari status kepemilikan rumah tersebut perlu dijelaskan bagaimana jenis rumah yang mereka tempati apakah rumah kayu/papan dan rumah permanen.

Dari status kepemelikan rumah responden di atas menunjukkan bahwa responden yang menempati di rumah milik sendiri tinggal bersama istri/suami dan anak-anak atau mereka adalah responden yang telah lama berdagang di Pasar Bersehati sehinggah bisa membangun rumah permanen atau rumah milik sendiri. Responden yang tinggal dirumah sewa atau rumah kontrakan dan rumah yang menumpang yaitu responden yang belum mampu membangun rumah karena keterbatasan ekonomi dan rumah yang menumpang terdapat 3 orang responden yang masih sementara menumpang Bersama teman dan tinggal di dalam Pasar Bersehati dengan tempat tinggal hanya berupa rumah papan atau kios kecil.

\section{Pengalaman Berdagang Responden}

Pengalaman sebelum menekuni pekerjaan sebagai pedagang sayur dan rempah-rempah. Pengalaman berdagang yang 
dimiliki oleh responden merupakan hal penting dalam proses kegiatan berdagang setiap hari di Pasar Bersehati Manado. Proses berdagang yang dilihat dari pengalaman sebelum berdagang sayur dan rempah-rempah dapat dilihat dapat dilihat pada Tabel 7.

Tabel 7. Pengalaman Berdagang Pedagang Sektor Informal di Pasar Bersehati Kota Manado

\begin{tabular}{lcrcr}
\hline & \multicolumn{2}{c}{ Pedagang Sayur } & \multicolumn{2}{c}{ Pedagang Rempal-Rempah } \\
\hline Lama Berdagang & Responden (orang) & Persentase $(\%)$ & Responden (orang) & Persentase $\left({ }^{\circ}\right)$ \\
\hline 0.9 & 2 & 13,3 & - & $\cdot$ \\
$10-19$ & 12 & 80 & 14 & 93,3 \\
$20-30$ & 1 & 6,7 & 1 & 6,7 \\
\hline Jumlah & 15 & 100 & 15 & 100 \\
\hline
\end{tabular}

Sumber: Diolah Dari Data Primer, 2017

Tabel 7 menunjukkan bahwa pengalaman berdagang responden dengan kisaran 2 bulan 30 tahun. Pedagang bekerja 2 - 9 bulan yaitu pedagang baru menekuni berdagang di sektor informal dan responden yang telah lama berdagang yaitu responden yang sebelumnya sudah pernah bekerja, sebagai petani, buruh, dan berdagang pakaian. Responden yang telah lama ada pengalaman sebelumnya mereka sudah mempunyai skill dibidang sektor informal oleh sebab itu saat memasuki berdagang sayur dan rempah sudah anggap lebih berpengalaman.

\section{Curahan Waktu Responden}

Dari lamanya jam kerja kita dapat melihat produktivitas dari setiap pekerja. Dari hasil wawancara dengan responden di peroleh bahwa waktu berdagang rata-rata 12 jam per hari. Untuk lebih jelasnya dapat dilihat paad Tabel 8.

Tabel 8. Curahan Waktu Berdagang Pedagang Sayur dan Pedagang Rempah-Rempah dalam Sehari di Pasar Bersehati Kota Manado

\begin{tabular}{|c|c|c|c|c|}
\hline \multirow[b]{2}{*}{$\begin{array}{l}\text { Curahan Waktu } \\
\text { Berdagang }\end{array}$} & \multicolumn{2}{|c|}{ Pedagang Saỹu } & \multicolumn{2}{|c|}{ Pedagang Rempah-Rempah } \\
\hline & Responden (orang) & Persentase $\left({ }^{\circ} \%\right)$ & Responden (orang) & Persentase $\left({ }^{\circ} \%\right)$ \\
\hline $0-4$ & $\cdot$ & - & - & - \\
\hline $5-9$ & 13 & 86,7 & 12 & 80 \\
\hline $10 \cdot 15$ & 2 & 13,3 & 3 & 20 \\
\hline Jumlah & 15 & 100 & 15 & 100 \\
\hline
\end{tabular}

Sumber: Diolah Dari Data Primer, 2017

Tabel 8 menunjukkan bahwa lamanya curahan waktu berdagang yang digunakan oleh responden akan berpengaruh pada produktivitas kerja. Pada umumnya responden mempunyai waktu berdagang rata-rata 11 jam yaitu mulai dari jam 06.00 wita pagi sampai jam 13.000 wita siang untuk pedagang sayur dan 06.00 wita pagi sampai jam 20.000 wita malam untuk pedagang rempah-rempah-rempah. Responden sebagian besar responden bekerja di siang hari dan ada di malam hari. Responden dengan curahan waktu per hari 5 sampai 9 jam waktu kerjanya adalah dari pagi jam 06.00 wita sampai siang jam 13.00 wita. Responden dengan curahan jam kerja 10 - 15 jam per hari memulai berdagang dari paagi jam 06.00 wita sampai malam jam jam 20.00 wita. Responden yang mempunyai waktu panjang merupakan pedagang yang mempunyai tempat tinggal berdekatan dengan pasar, adapun pedagang yang bertempat tinggal jauh mereka datang mulai dari jam 04.00 pagi selesai ibadah subuh hinggah malam jam 20.15 wita sampai persiapan pulang ke rumah.

\section{Tenaga Kerja Responden}

Tenaga kerja yaitu orang lain yang ikut membantu usaha yang dijalankan oleh responden yang dimulai dari persiapan sampai berakhirnya berdagang di Pasar Bersehati Manado. Pekerjaan ini membutuhkan waktu cukup tinggi maka pedagang menggunakan tenaga kerja dalam keluarga, luar keluarga, dan tidak menggunakan tenaga kerja dan lebih jelasnya dapat dilihat pada Tabel 9.

Tabel9. Tenaga Kerja Pedagang Sayur dan Pedagang. Rempah-Rempah di Pasar Bersehati Kota Manado.

\begin{tabular}{lcccr}
\hline \multicolumn{5}{c}{ Jenis Pedagang } \\
\hline $\begin{array}{l}\text { Pengguman } \\
\text { Tenaga Kerja }\end{array}$ & Pedagang Sag̣u & Persentase $(\%)$ & $\begin{array}{c}\text { Pedagang } \\
\text { Rempah-Rempah }\end{array}$ & Persentase $(\%)$ \\
\hline TKDK & 1 & 6,7 & 3 & 20 \\
TKLK & 14 & 93,3 & 12 & 80 \\
\hline Jumlah & 15 & 100 & 15 & 100 \\
\hline
\end{tabular}

Sumber: Diolah Dari Data Primer, 2017

Tabel 9 menunjukkan bahwa reponden memperkerjakan orang lain untuk membantu kelancaran berdagang. Kelancaran berdagang pada setiap responden tentunya tidak bisa mengerjakan sendiri tentunya perlu ada tenaga yang ikut sertakan membantu agar proses berdagang dapat berjalan dengan baik dan mengaji atau memberikan upah kepada tenaga yang ikut membantu responden. Tenaga yang ikut sertakan diri untuk membantu dengan diberikan upah oleh reponden yaitu Tenaga Kerja Dalam Keluarga (TKDK) dan Tenaga 
Kerja Luar Keluarga (TKLK). responden yang mengerjakan tenaga kerja dalam keluarga merupakan tenaga yang membantu reponden dengan diberikan upah atau gaji per hari. Tenaga kerja dalam keluarga mengerjakan pekerjaannya tidak menetap artinya mereka hanya kerja kalau responden perlu untuk mengatasi semua dagangannya misalnya menjaga atau mengkontrol dagangan responden dan tenaga kerja luar keluarga bekerja mulai dari persiapan sampai berakhirnya aktivitas berdagang. Upah yang diterima setiap tenaga kerja berbeda karena responden memberikan upah tenaga kerja disesuaikan dengan kapasitas sayur dan rempah-rempah yang dijual di Pasar Bersehati Manado.

\section{Motivasi Responden}

Motivasi berdagang merupakan semangat untuk memulai usaha. Motivasi pedagang untuk lebih jelasnya dapat dilihat pada Tabel 10.

Tabel 10. Motarasi Pedagang Sektor Informal di Pasar Bersehati Kota Manado

\begin{tabular}{|c|c|c|c|c|}
\hline \multicolumn{2}{|c|}{ Pedaging Saxur } & \multicolumn{3}{|c|}{ Pedagang Rempal-Rempal } \\
\hline Motivasi Nemulai Berragang & Responden (orang) & Persentase $(\%)$ & Responden (orang) & Persentase $(\%)$ \\
\hline Dorongan dalam diri & 14 & 93,3 & 15 & 100 \\
\hline Dorongan keluarga & 1 & 6,7 & . & \\
\hline Jumlah & 15 & 100 & 15 & 100 \\
\hline
\end{tabular}

Tabel 10 menunjukkan bahwa hasil penelitian sosial ekonomi yang dilakukan di Pasar Bersehati Manado dilihat dari semua karakteristik sosial yang telah dikemukakan sebelumnya bahwa dasar untuk memulai suatu usaha atau berdagang diperlukan jiwa semangat yang kuat agar kemampuan untuk menghidupkan ekonomi keluarag bisa terpenuhi dengan baik. Tabel 10 yang telah dilihat besar kecilnya persentase dapat berpengaruh pada motivasi disetiap responden yakni pedagang sayur dan pedagang rempah-rempah. Rata-rata jawaban yang telah diterima dari hasil wawancara pada setiap responden mengatakan bahwa motivasi atau dorongon yang ada dalam diri sangat penting untuk menciptakan semnagat dan kemampuan untuk maju dan semangat di setiap responden dapat berpengaruh pada tingkat pendapatan yang diterima sekali penjualan.

\section{Karakteristik Ekonomi Pedagang di Sektor Informal}

\section{Modal Yang di Gunakan Responden}

Pedagang mendapatkan modal dalam menjalankan usahanya tentunya, membutuhkan modal guna menunjang usaha mereka. Modal usaha yang dijalani berupa modal dalam bentuk uang, barang dan jasa serta modal kepercayaan. Tabel 11 menunjukkan sumber modal dari usaha yang dijalankan oleh pedagang sayur dan pedagang rempah-rempah.

Tabel 11. Sumber Modal Usaha Pedagang Sayur dan Pedagang Rempah-Rempah di Pasar Bersehati Kota Manado

\begin{tabular}{lcrcr}
\hline \multicolumn{4}{c}{ Pedagang Sayur } & \multicolumn{2}{c}{ Pedagang Rempah-Rempah } \\
\hline Sumber Modal & Responden (orang) & Persentase (\%) & Responden (orang) & Persentase (\%) \\
\hline Modal Sendiri & 15 & 100 & 13 & 86,7 \\
Modal Kepercayaan & - & - & 2 & 13,3 \\
\hline Jumlah & 15 & 100 & 15 & 100 \\
\hline
\end{tabular}

Tabel 11 menunjukkan bahwa rata-rata responden memiliki modal sendiri. Responden menabung sudah lama sehingga modal yang akan dikeluarkan mampu membeli sayur dan rempah-rempah dengan kapasitas yang berbedaberbeda.

Modal Kepercayaan dalam proses kegiatan berdagang merupakan modal yang diartikan di Pasar Bersehati manado dengan istilah titip sayur atau rempah-rempah. Pedagang mengambil berbagai jenis sayur dan jenis rempah-rempah yang berada di belakang pasar Bersehati Manado. Responden mengambil sayur dan rempah saat memulai berdagang dari pagi jam 03.00 wita di pelelangan dan ada juga langsung diantar dari Minahasa, Langowan, dan Gorontolo langsung ke tempat pemilik pedagang. Setelah sayur dan rempah-rempah sudah ditempat maka dari hasil berdagang akan diberikan setengah ke pemilik pelelangan atau istilah pasar dengan sebutan stor hasil dangangan. Besar modal berdagang sayur dan rempah-rempah dalam penjualan untuk lebih jelasnyadapat dilihat pada Tabel 12 .

Tabel 12. Modal Yang di Keluarkan Oleh Pedagang Sayur dan Pedaang Rempah-Rempah dalam Proses Penjualan di Pasar Bersehati Kota Manado

\begin{tabular}{lcrcr}
\hline & \multicolumn{3}{c}{ Pedagang Sayur } & \multicolumn{2}{c}{ Pedagang Rempah-Rempah } \\
\hline Modal Pembelian & Responden (orang) & Persentase $\left({ }^{\circ} \%\right)$ & Responden (orang) & Persentase $\left({ }^{\circ}\right.$ ) \\
\hline Modal Kepercayaan & 2 & 13,3 & 2 & 13,3 \\
$5000,000,-1,000,000$ & 6 & 40 & 4 & 26,7 \\
$1,500,000,-2,000,000$ & 4 & 26,7 & 5 & 33,3 \\
$2,500,000,-3,000,000$ & 3 & 20 & 4 & 26,7 \\
\hline Jumlah & 15 & 100 & 15 & 100 \\
\hline
\end{tabular}


Tabel 12 menunjukkan bahwa modal yang digunakan akan menentukan seberapa banyak jenis sayuran dan rempah-rempah yang akan dijual dan responden memiliki modal yang beragam. Keberagaman modal ini disebabkan karena masing-masing pedagang tidak ada yang melakukan peminjaman modal melalui bank karena, akses peminjaman yang besar. Pengambilan modal yang tidak mampu mengambil modal pinjaman merupakan salah satu bentuk ketidakmampuan akan modal dasar berdagang oleh karena itu terdapat 4 orang yang memakai modal kepercayaan untuk memenuhi kebutuhan dasar berdagang sayur dan rempahrempah. Besarnya modal yang dikeluaran oleh responden sangat mempengaruhi pengambilan sayur dan rempah-rempah untuk di jual ke konsumen, semakin besar modal pedagang maka semakin banyak produk yang dijual setiap hari.

\section{Penerimaan Responden di Pasar Bersehati Kota Manado}

Penerimaan merupakan sayur dan rempahrempah yang di jual ke konsumen untuk mengahasilkan pendapatan. Penerimaan yang didapat oleh reasponden memperoleh rata-rata hasil sekali penjualan tertinggi terdapat pada pedagang rempah-rempah sebesar $\mathrm{Rp} 597,947$ dengan rata-rata harga jual rempah-rempah $\mathrm{Rp}$ 19,656 dan pedagang sayur mempunyai hasil yang diterima dari sekali penjualan yaitu Rp 256,250 dengan rata-rata harga jual sayur Rp 9,033.

\section{Pengeluaran Responden di Pasar Bersehati Manado}

Pengeluaran merupakan biaya-biaya yang dikeluarkan secara langsung oleh pedagang sayur dan pedagang rempah-rempah.

Biaya yang dikeluarkan yaitu biaya variabel dan biaya tetap sekali penjualan. Pengeluaran pedagang sayur dan pedagang rempah-rempah dapat dilihat pada Tabel 13.

\begin{tabular}{lrr} 
Tabel 13. $\begin{array}{l}\text { Rata-Rata Pengeluaran Biaya Variabel, Biaya Tetap dan Total Biaya Pada Pedagang } \\
\text { Sayur dan Pedagang Rempal-Rempah Per Hari }\end{array}$ \\
\hline Uraian & Pedagang Sayur (Rp) & Pedagang Rempah-Rempah (Rp) \\
\hline Pembelian Produk & 135,000 & 229,056 \\
PengangkutanProduk & 8,233 & 11,272 \\
Kantong Plastik & 10,854 & 10,917 \\
Tenaga Kerja & 4,762 & 10,633 \\
\hline Jumlah Biaya Variabel (A) & 158,849 & 261,881 \\
\hline Sewa Tempat & 7,689 & 146,417 \\
Kebersihan & 9,000 & 5,783 \\
Retribusi & 6,444 & 8,383 \\
Listrik & 10,400 & 15,533 \\
\hline Jumlah Biaya Tetap (B) & 33,533 & 176,116 \\
\hline Total Biaya (C)=(A)+(B) & 192,382 & 437,997 \\
\hline
\end{tabular}

Tabel 13 menunjukkan bahwa biaya-biaya yang dikeluarkan dalam sekali berdagang yaitu untuk mempermudah dalam proses berdagang, dari biaya-biaya diatas akan berpengaruh pada pendapatan pedagang. Pengeluaran atau biayabiaya yang dikeluarkan selama proses berdagang dalam sehari penuh. Total biaya yang tertinggi yang dimiliki oleh pedagang rempah-rempah sebesar RP 437,997 dan biaya terendah di ikuti oleh pedagang sayur yaitu 192,382. Hasil dari pengeluaran di biaya variabel dan biaya tetap bahwa yang paling tinggi yaitu terdapat di pedagang rempah-rempah. Hal ini menunjukkanmenunjukkan bahwa semakin tinggi biaya yang dikeluarkan akan menambah pendapatan atau keuntungan selam proses berdagang di Pasar Bersehati Manado.

\section{Pendapatan Responden di Pasar Bersehati Manado}

Pendapatan merupakan hasil pengurangan dari total biaya variabel dan biaya tetap. Hasil pendapatan dari jenis pedagang dapat dilihat pada Tabel 14.

Tabel 14. Pendapatan Responden 7 jam dan 15 jam Per Hari

\begin{tabular}{|c|c|c|}
\hline \multicolumn{3}{|c|}{ Rata-Rata Pendapatan Setengah Hari dan Satu Hari (Rp) } \\
\hline \multicolumn{3}{|l|}{ Pedagan Sayur } \\
\hline Penerimaan $(\mathrm{Rp} / \mathrm{Kg})$ & Total Biaya (Rp) & Pendapatan $(\mathrm{Rp}$ \\
\hline 256,250 & 192,382 & 63,868 \\
\hline \multicolumn{3}{|l|}{$\begin{array}{l}\text { Pedagang Rempah- } \\
\text { Rempah }\end{array}$} \\
\hline Penerimaan $(\mathrm{Rp} / \mathrm{Kg})$ & Total Biaya (Rp) & Pendapatan $(\mathrm{Rp})$ \\
\hline 597,947 & 437,997 & 276,950 \\
\hline
\end{tabular}

Tabel 14 menunjukkan bahwa pendapatan yang diterima pada setiap responden digunakan sebagai indikator sosial ekonomi yang dipakai untuk melihat pembangunan secara umum Kota Manado dan Pasar Bersehati Kota Manado. Tinggi rendahnya pendapatan responden yang berdagang sayur dan rempah-rempah akan mempengaruhi sikap pedagang sektor informal, khususnya responden yang berdagang sayur dan rempah-rempah dalam mengatur perilaku ekonomi. Pendapatan dalam hal ini merupakan pendapatan dari hasil penjualan sayur dan rempah-rempah yang lakukan sekali penjualan. 
Berdasarkan Tabel 14 rata-rata pendapatan pada pedagang sayur mempunyai pendapatan rendah $\mathrm{Rp}$ 63,868 dan rata-rata pendapatan yang diterima oleh pedagang rempah-rempah memperoleh pendapatan tertinggi sebesar Rp 276,950.

\section{Ikhtisar atau Ringkasan Hasil Penelitan Sosial Ekonomi}

Kesimpulan atau pendapat terakhir yang mengandung informasi berdasarkan uraian variabel penelitian dan fakta atau alasan terhadap objek yang telah diteliti di Pasar Bersehati Manado. Ikhtisar atau ringkasan hasil penelitian dilapangan dapat dilihat pada Tabel 15.

\begin{tabular}{|c|c|c|c|}
\hline $\begin{array}{c}\text { Karakteristik } \\
\text { Sosial }\end{array}$ & Ilkhtisar Penelitian & $\begin{array}{c}\text { Karakteristik } \\
\text { Ekonomi }\end{array}$ & Ikhtisar Penelitian \\
\hline Daerah asal & \begin{tabular}{l}
\multicolumn{3}{l}{ Migrasi dari asal daerah } \\
terbesar dari yaitu \\
Gorontalo \\
pedagang sayur dan \\
86,7 di pedagang \\
rempah-rempah
\end{tabular} & Modal & $\begin{array}{l}\text { Menggunakan } \\
\text { modal sendin dan } \\
\text { modal asaspercaya. }\end{array}$ \\
\hline $\begin{array}{l}\text { Status } \\
\text { Perkawinan } \\
\text { dan } \\
\text { Tanggungan } \\
\text { Keluarga }\end{array}$ & $\begin{array}{l}86.7 \% \text { responden telah } \\
\text { menikah pedag-ang } \\
\text { sayur dan } 100 \% \text { di } \\
\text { pedagang rempah- } \\
\text { rempah serta tanggu- } \\
\text { ngan keluarga rata-rata } \\
5-7 \text { orang. }\end{array}$ & \multirow{5}{*}{$\begin{array}{l}\text { Penerimaan, } \\
\text { Pengeluaran, } \\
\text { danpendapatan } \\
\text { pedagang sayur } \\
\text { dan pedagang } \\
\text { rempah yang } \\
\text { berdagang di } \\
\text { Pasar Bersehati } \\
\text { Kota Manado. }\end{array}$} & \multirow{5}{*}{$\begin{array}{l}\text { Hasil penjualan dan } \\
\text { biaya yang } \\
\text { dikeluarkan } \\
\text { berpengaruh pada } \\
\text { tingkat pendapatan } \\
\text { pedagang dalam } \\
\text { sehar sehinggga } \\
\text { pendapatan yang } \\
\text { menguntungkan Rp } \\
63,868 \text { di pedagang } \\
\text { sayur dan Rp } \\
276,950 \text { di pedagang } \\
\text { rempah-rempah } \\
\text { untuk menghidupi } \\
\text { kebutuhan keluarga } \\
\text { selama tinggal di } \\
\text { Manado. }\end{array}$} \\
\hline $\begin{array}{l}\text { Tempat } \\
\text { Tinggal }\end{array}$ & $\begin{array}{l}\text { Mendiami numah milik } \\
\text { sendiri } 66,7 \% 93,3 \% \text {. }\end{array}$ & & \\
\hline $\begin{array}{l}\text { Waktu } \\
\text { Berdagang }\end{array}$ & $\begin{array}{l}\text { Berdagang dalam sekali } \\
\text { penjualan rata-rata } 7-9 \\
\text { jam/hari. }\end{array}$ & & \\
\hline Tenaga Kerja & $\begin{array}{l}\text { Pedagang sayur dan } \\
\text { pedagang rempa- } \\
\text { rempah rata-rata } \\
\text { menggunakan tenaga } \\
\text { kerja } 93,3 \% \text { dan } 80 \% \\
\text { dari luar keluarga }\end{array}$ & & \\
\hline Motivasi & $\begin{array}{l}\text { Membangun semangat } \\
\text { dalam diri sendiri yakni } \\
93,3 \%\end{array}$ & & \\
\hline
\end{tabular}

\section{KESIMPULAN DAN SARAN}

\section{Kesimpulan}

Berdasarkan hasil penelitian sosial ekonomi pedagang sektor informal di Pasar Bersehati Kota Manado maka dapat ditarik kesimpulan sebagai berikut:

1) Dilihat dari aspek sosial, para pedagang sektor informal di Pasar Bersehati Kota Manado memiliki latar belakang keluarga yang sederhana dengan berbagai keterbatasan sosial ekonomi. Para pedagang tersebut berasal dari dalam Manado dan luar Manado yakni Gorontalo dan Ternate yang berdagang sebagai penjual atau pedagang sayur dan pedagang rempah-rempah. Latar belakang Pendidikan formal rendah sampai sedang (SMA) para pedagang tersebut memiliki motivasi yang sangat tinggi dengan bekerja rata-rata 7 jam/hari untuk pedagang sayur dan 9 jam untuk pedagang.

2) Dilihat dari aspek ekonomi, sektor informal memperoleh pengahasilan yang terbatas untuk memenuhi kebutuhan hidup keluarga sehari-hari. Pedagang memiliki modal sendiri dan mempunyai tempat tempat tinggal sendiri dan sebagiannya lagi tidak memiliki modal dagangan namun, mampu bertahan hidup untuk dan memenuhi kebutuhan keluarga mereka setiap hari.

\section{Saran}

1) Bagi Pemerintah Kota Manado, perlu memberikan pembinaan dalam upaya memperbaiki kinerja usaha pedagang sektor informal di Kota Manado. Para pedagang sektor informal perlu diberikan tempat khusus sehingga mereka, tidak lagi menjajakan barang dagangannya di jalur jalan atau di trotoar jalan.

2) Bagi Pedagang, para pedagang sektor informal di Pasar Bersehati Kota Manado perlu meningkatkan kapasitas mereka baik secara individu maupun secara kelompok agar mereka bisa meningkatkan kinerja usaha untuk memperbaiki taraf hidup dan kesejahteraan selama bekerja sebagai pedagang pada sektor informal di Kota Manado.

\section{DAFTAR PUSTAKA}

Nugroho, F. A. 2010. Penataan Sektor Informal di Belakang Kampus UNS. Studi Kasus Dampak Sosial Ekonomi Pada Pedagang di Pasar.Skripsi. Universitas Sebelas Maret. Surakarta.

Rachbini, D. J dan Hamid, A. 1994. Ekonomi Informal Perkotaan. PT Pustaka Hal 1-50. LP3ES. Jakarta.

Nussbaum, M dan Sen, A.1993. Kualitas Hidup. Pers Universitas Oxford. New York. 